\title{
The Multifaceted Effects of Omega-3 Polyunsaturated Fatty Acids on the Hallmarks of Cancer
}

\author{
J. A. Stephenson, ${ }^{1,2}$ O. Al-Taan, ${ }^{1,3}$ A. Arshad, ${ }^{1,3}$ B. Morgan, ${ }^{1,2}$ \\ M. S. Metcalfe, ${ }^{3}$ and A. R. Dennison ${ }^{3}$ \\ ${ }^{1}$ Department of Cancer Studies and Molecular Medicine, University of Leicester, Leicester Royal Infirmary, Leicester LE1 5WW, UK \\ ${ }^{2}$ Department of Imaging, Leicester Royal Infirmary, Leicester LE1 5WW, UK \\ ${ }^{3}$ Department of Surgery, University Hospitals of Leicester, Leicester General Hospital, Leicester LE5 4PW, UK
}

Correspondence should be addressed to J. A. Stephenson; jastephenson@doctors.org.uk

Received 20 January 2013; Revised 26 March 2013; Accepted 5 April 2013

Academic Editor: Angel Catala

Copyright $\odot 2013$ J. A. Stephenson et al. This is an open access article distributed under the Creative Commons Attribution License, which permits unrestricted use, distribution, and reproduction in any medium, provided the original work is properly cited.

Omega-3 polyunsaturated fatty acids, in particular eicosapentaenoic acid, and docosahexaenoic acid have been shown to have multiple beneficial antitumour actions that affect the essential alterations that dictate malignant growth. In this review we explore the putative mechanisms of action of omega-3 polyunsaturated fatty acid in cancer protection in relation to self-sufficiency in growth signals, insensitivity to growth-inhibitory signals, apoptosis, limitless replicative potential, sustained angiogenesis, and tissue invasion, and how these will hopefully translate from bench to bedside.

\section{Introduction}

Fatty acids (FAs) are a diverse group of molecules. The fatty acyl structure represents the major building block of complex lipids and FAs should be regarded as one of the most fundamental categories of biological lipids [1]. Fatty acids are key nutrients that affect early growth and development, as well as chronic disease in later life. The benefits and potential risks of FAs go well beyond their defined role as fuel [2].

An FA containing more than one carbon double bond is termed polyunsaturated fatty acid (PUFA). The most important families in human metabolism are omega-6 (n-6) and omega-3 (n-3) PUFAs. Specific n-6 and n-3 PUFAs are essential nutrients, while the eicosanoids and docosanoids they derive have distinct biological activities affecting the prevalence and severity of cardiovascular disease, diabetes, inflammation, cancer, and age-related functional decline $[1,2]$.

Important n-3 PUFAs involved in human nutrition are $\alpha$ linolenic acid (ALA or 18:3n-3), eicosapentaenoic acid (EPA or 20:5n-3), docosapentaenoic acid (n-3 DPA or 20:5n-3), and docosahexaenoic acid (DHA or 22:6n-3).

ALA is the parent FA of the n-3 PUFA family. ALA is mainly found in the plant kingdom with high concentrations in flaxseed oil and perilla oil. It is also found in canola oil, soybean oil, and vegetable oils from where humans derive it in their diet. The human body is unable to readily synthesize ALA, which makes ALA, like linoleic acid (LA or $18: 2 n-6$ ), the parent of the n-6 PUFA family, an essential fatty acid [1].

LA and ALA are converted to their respective n- 6 and n-3 PUFA families by a series of independent reactions. However both pathways require the same enzymes for desaturation and elongation. This leads to competition between n-6 and n-3 PUFA for their metabolic conversion. The first step in the pathway requires $\Delta 6$ Desaturase $[3,4]$ which has a higher affinity for ALA than LA but due to the typically higher intake and concentration of LA there is greater conversion of n-6 PUFA producing the predominant product of the n-6 pathway, arachidonic acid (AA or 20:4n-6) [1,5-7]. Thus the capacity of human metabolism to derive EPA and DHA by the desaturation of ALA is negligible in normal circumstances [1]. The efficiency of conversion is particularly poor in relation to DHA $[6,8]$. The concentration of EPA and DHA in tissues can however be enhanced by direct ingestion of either oily fish or as a fish oil (FO) supplement or when competing amounts of n-6 PUFAs are relatively small [8-10].

Fish are able to build up large concentrations of $n-3$ PUFAs in their tissues by consuming algae and plankton 
and are therefore the main dietary source of essential n-3 PUFAs in humans. In particular cold-water oily fish such as mackerel, salmon, herring, anchovies, sardines, and smelt provide relatively large amounts of EPA and DHA [7].

\section{Physiological Effects of Omega-6 and Omega-3 Polyunsaturated Fatty Acids}

n-6 and n-3 PUFAs have a number of vital functions in the human body $[11,12]$. As components of structural phospholipids in the cell membrane, they modulate cellular signaling, cellular interaction, and membrane fluidity [13].

They regulate the immune system by acting as precursors for eicosanoids-potent immunoregulatory metabolites. Eicosanoids are synthesised from the n-6 PUFA arachidonic acid (AA, 20:4n-6) and the n-3 PUFA, EPA. AA and EPA are metabolised by cyclooxygenase (COX) or lipoxygenase (LOX) enzymes into immunoregulatory metabolites prostaglandins (PGs), thromboxanes (TXs), and leukotrienes (LTs) [13]. As cell membrane phospholipids generally contain significantly higher levels of AA than EPA [14], AA is the most common eicosanoid precursor and gives rise to 2-series PGs and TXs and 4-series LTs. EPA gives rise to 3-series PGs and TXs, 5-series LTs, and E-series resolvins [13, 15].

DHA is a poor substrate for COX and LOX and it was thought that DHA did not produce bioactive COX and LOX mediators. However, Serhan and others identified bioactive docosanoids, named D-series resolvins and protectins [1517].

AA and EPA also compete for the COX and LOX enzymes. Again, n-3 PUFAs are preferentially used, so supplementation with n-3 PUFAs will have a considerable impact on the production of eicosanoids and docosanoids. Thus, increased intake of n-3 PUFAs results in decreased generation of AA-derived eicosanoids and increased EPA derived eicosanoids and DHA docosanoids [18-21].

It is considered that the eicosanoids and docosanoids produced from EPA and DHA have less biological activity. Therefore have the advantage of being less pro-inflammatory in their action than the potent pro-inflammatory AA-derived mediators $[13,16,22]$. It is also suggested that they also have properties which are anti-inflammatory [15-17].

This theoretical benefit is the rationale for the use of FO supplements in chronic inflammatory disease such as asthma [23] and rheumatoid arthritis [22]. It is also why there is significant interest in the use of n-3 PUFA supplementation in critically ill patients and in patients undergoing major surgery [24-38].

\section{The Role of Polyunsaturated Fatty Acids in Tumourigenesis}

Hanahan and Weinberg in their landmark review "The hallmarks of cancer" and the subsequent "Hallmarks of the Cancer: the next generation" suggested that the vast catalog of cancer cell genotypes is a manifestation of essential alterations in cell physiology that collectively dictate malignant growth $[39,40]$.
The original six essential alterations described are self-sufficiency in growth signals, insensitivity to growthinhibitory (antigrowth) signals, evasion of programmed cell death (apoptosis), limitless replicative potential, sustained angiogenesis, and tissue invasion and metastasis. This results in the cancerous cell having the predatory properties that allow it to survive, invade, and multiply where it should not. Recently the addition of reprogramming of energy metabolism and evading immune destruction has been suggested. Each of these physiologic changes (novel capabilities acquired during tumor development) represents the successful breaching of anticancer defense mechanisms. They proposed that these capabilities are shared in common by most and perhaps all types of human tumors and must be satisfied for tumour growth to occur within the tumour microenvironment $[39,40]$.

EPA and DHA have been shown to have multiple antitumour actions that affect all of the original six essential alterations that dictate malignant growth. This is a result of various pathways including inhibition of AA metabolism and independent effects on various cytokines involved in tumourigenesis. n-6 PUFA derived eicosanoids have promoting effects in cancer cell growth [41, 42], angiogenesis [42], and invasion [43]. As previously discussed n-3 PUFAs can also be metabolized to resolvins and protectins $[15,44]$. These compounds possess immunoregulatory actions [45] and it is well documented that inflammation plays an important role in the development of numerous human malignancies [46-48]. Thus one of the possible mechanisms for inhibition of tumor growth by n-3 PUFAs is via immunoregulation through production of 5 series leukotrienes (LT), 3 series prostaglandins (PG) and thromboxanes (TX), and resolvins-Figure 1 [49].

\section{Effects of Omega-3 Polyunsaturated Fatty Acids on Growth Signals}

Normal cells are unable to proliferate in the absence of stimulatory signals from transmembrane receptors, which are activated by growth factors, extracellular matrix components, and cell-cell interaction molecules [39]. Conversely, tumour cells however have a reduced dependence on such exogenous growth signals. Cancerous cells often bypass this step by synthesizing their own growth factors [50], overexpressing cell surface receptors which transmit growth-stimulatory signals $[50,51]$ or switching integrins to ones which favour growth signal transition [39-52]. Also many oncogenes mimic normal growth signals, promoting proliferation [39, 53].

The overall result is that the cancer cell is self sufficient in stimulating its own multiplication. The reduced dependence on exogenous growth signals and stimulation from normal tissue microenvironment leads to unregulated and exponential growth.

4.1. In Vitro Evidence. The cell plasma membrane affects growth factor: receptor interaction and subsequent signal transduction. EPA and DHA have been shown to have beneficial effects on the plasma membrane in MDA-MB-231 
Anti-inflammatory mediation
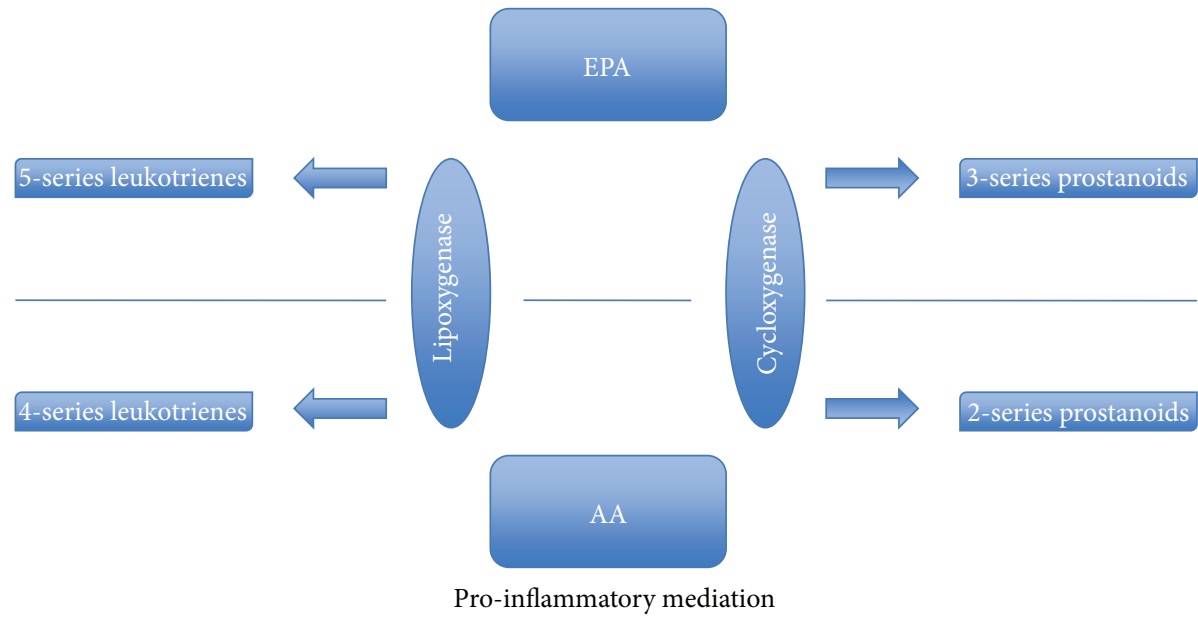

FIGURE 1: Inflammatory mediators derived from eicosapentaenoic acid and arachidonic acid. Adapted From Furst 2000.

breast cancer cells with a marked decrease of epidermal growth factor receptor (EGFR) in lipid rafts, leading to alteration in EGFR signaling in a way that decreases the growth of breast tumors [54].

n-3 PUFAs appear to downregulate protein kinase $C \beta 2$ $[55,56]$, RAS [57], and nuclear factor $\kappa \beta(\mathrm{NF}-\mathrm{kB})[58]$ which are important cell signaling mediators often found to be elevated in carcinogenesis.

DHA has also been shown to modulate heat shock proteins that act as "chaperones" in protein: protein interactions and in cell membrane transport. [59]. DHA is also known to modulate steroid receptors in human cancer cell lines [60].

Tumour derived nitric oxide (NO) has the ability to promote tumour growth by enhancing invasiveness of tumour cells $[61,62]$. NO also increases PGE2 production, which is implicated in tumour growth and progression [62]. EPA and DHA suppress NO production in macrophage cell lines in a dose dependant fashion $[63,64]$.

EPA and DHA inhibited human colon adenocarcinoma Caco- 2 cell proliferation. Cells cultured with EPA or DHA reached much lower final densities compared to cells cultured with LA. The authors proposed that low insulin growth factor II (IGF-II)/IGF binding protein-6 ratios may have resulted in less free IGF-II a potent cell proliferation promoter and, consequently, the slower proliferation of Caco-2 cells treated with EPA or DHA [65].

4.2. In Vivo Evidence. COX-2 over-expression has been reported in $90 \%$ of colon tumours and colonic adenomas [66]. COX-2 has direct and indirect effects on growth via upregulation of growth signals and prostaglandins, angiogenesis, apoptosis, and cell-cell interaction [67]. The specific effects will be discussed in each subsequent section. In relation to self-sufficiency, numerous studies have found that COX-2 and its active metabolite PGE2-levels are reduced by supplementation of $n-3$ PUFAs $[66,68,69]$. A prostate cancer cell xenograft in mice found that the reduced levels of COX-2 and PGE2 were related to a reduction in tumour growth rate, tumour volume, and serum PSA [70].
Protein kinase C (PKC) $\Delta$ has a tumour suppressor function. The carcinogen azoxymethane decreases levels of PKC $\Delta$. This decrease has been shown to be ameliorated in rats feed FO [71]. PKC $\beta 2$, which is induced early in colon carcinogenesis, leading to self-sufficiency, cancer promotion, and carcinogen induced epithelial hyper-proliferation [7276], is significantly decreased in rats fed FO. This blocked PKC $\beta 2$ hyperproliferation [74, 77].

The effect of n-3 PUFAs on growth signal transduction appears to be multi-faceted, with numerous putative pathways identified in the in vitro and in vivo setting (Figure 2). This suggests that any relationship of n-3 PUFA on tumourigenesis is complex.

\section{Effects of Omega-3 Polyunsaturated Fatty Acids on Tumour Insensitivity to Growth-Inhibitory Signals}

Tissue homeostasis and cellular quiescence is maintained in normal cells by anti-proliferative signals from growth inhibitory factors (tumour suppressor genes) and from cellcell or cell-extracellular matrix interaction. These antigrowth signals are transmitted by cell surface receptors and may have 2 potential effects: (1) cells are forced into the quiescent (G0) state; (2) cells are induced into a post-mitotic state of permanent dormancy [39].

5.1. In Vitro Evidence. Investigation of the effect of EPA and DHA on colon cancer cell lines has shown decreases in cellular proliferation. Mengeaud demonstrated that cellular proliferation in HRT-18, HT-29, and Caco-2 cell lines is decreased by EPA [78]. This was replicated in a SIC oncogene transformant cell line by Tsai who also showed that DHA reduced cellular proliferation [79]. In two studies using HT-29 cell lines Clarke reported that EPA reduced cell proliferation and Chen demonstrated that DHA had a similar effect $[80,81]$. Other studies have also shown decreases in cell proliferation in response to EPA and DHA $[65,82]$. 


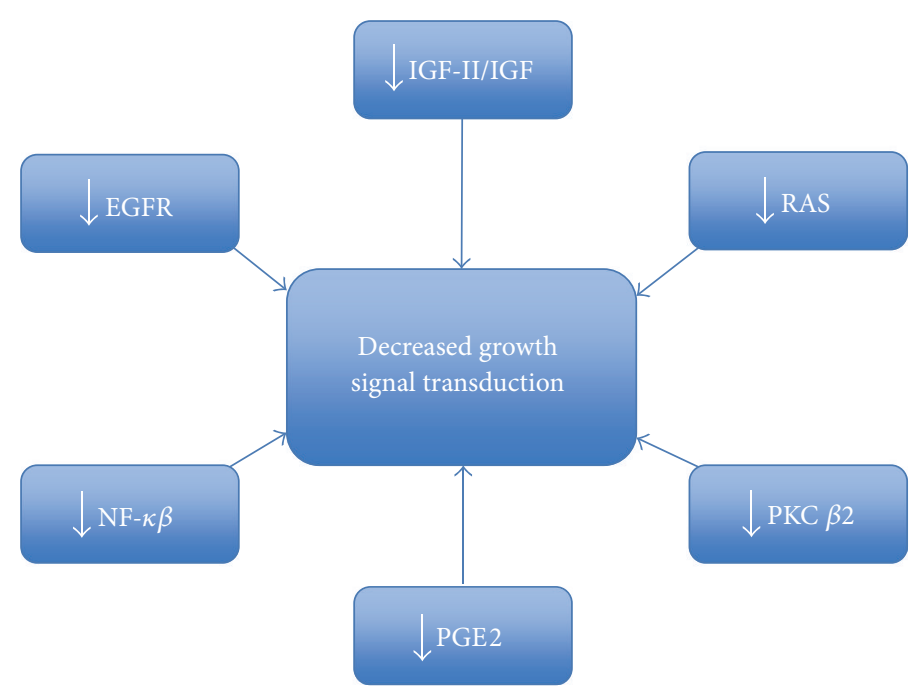

FIGURE 2: Multi-modal putative mechanisms of action of DHA and EPA on growth signal transduction.

5.2. In Vivo Evidence. In a rodent model of breast cancer, DHA induced a reduction in mammary tumours accompanied by a $60 \%$ upregulation of BRCA1 tumour suppressor protein [83].

Numerous studies have shown a decrease in tumour cellular proliferation in response to n-3 PUFAs; however the putative mechanisms are not well documented and further investigation is required.

\section{Effects of Omega-3 Polyunsaturated Fatty Acids on Tumour Evasion of Programmed Cell Death}

Apoptosis governs the rate of cell attrition. The ability of tumour cells to expand in number is governed by the balance of proliferation and apoptosis. Evasion of apoptosis allows tumour cell mass to increase dramatically and it is a hallmark of tumourigenesis.

6.1. In Vitro Evidence. The studies previously reported on HT-29 colon cell lines by Clarke and Chen also showed increased induction of apoptosis with n-3 PUFAs [80, 81]. Other studies have shown that DHA induces a dosedependant effect upon cancer cell apoptosis [84-86].

DHA has been shown to induce cytochrome c release, which binds to apoptotic protease activating factor initiating cancer cell apoptosis [85, 87].

n-3 PUFAs alter peroxisome proliferator-activated receptors (PPARs) cell signaling by acting as direct ligands for the receptors. DHA has been shown to modulate PPAR receptor expression $[88,89]$ and induce cellular apoptosis $[67,90,91]$. This was mediated through the effect of PPAR on Syndecan-1 a protein product, which induces apoptosis $[67,91]$.

EPA and DHA have also been shown to modulate expression of the Bcl-2 family. They downregulate the expression of anti-apoptotic proteins $\mathrm{Bcl}-2$ and $\mathrm{Bcl}-\mathrm{xL}$ and increase levels of Bak and Bcl-xS pro-apoptotic proteins [92-97].
$\mathrm{NF} \kappa \beta$, which has the ability to block programmed cell death potentiating tumour survival, is downregulated by $n$ 3 PUFAs in murine macrophages, which decreases COX-2 expression restoring functional apoptosis $[23,98]$.

6.2. In Vivo Evidence. Hong showed that in a mouse model of colon carcinogenesis that initiation of tumour growth was restricted by increased apoptosis related to n-3 PUFA supplementation [99]. One way in which apoptosis may be regulated by $n-3$ PUFAs is via COX-2. COX-2 has been shown to decrease apoptosis via expression of the $\mathrm{Bcl}-2$ gene. A reduction of COX-2 and COX-2 inhibition have been shown to repress the expression of $\mathrm{Bcl}-2$ gene and its anti-apoptotic properties [67, 67, 69, 91].

The Bcl-2 family also has a pro-apoptotic member Bad. In its normal state Bad promotes cell death by displacing Bax from Bcl-2 [100, 101]. Phosphorylation of Bad prevents it from displacing $\mathrm{Bax}$ from $\mathrm{Bcl}-2$ subsequently promoting cell survival $[100,102,103]$. A study by Berquin on Pten knockout mice showed that prostate tumours from mice with an enriched n-3 PUFA diet had lower levels of phosphorylated Bad and higher apoptotic indexes compared to mice on an n-6 PUFA diet. This led to reduced tumour growth, slowed histopathological progression, and increased survival rates [49].

Tumour evasion of programmed cell death is a complex and controlled by an intricate milieu of intra-cellular signal transduction pathways and external cytokines, survival factors, chemokines, growth factors, and death factors. Evidence suggests that DHA and EPA have effects on many of these pathways, which seem to be beneficial.

\section{Effects of Omega-3 Polyunsaturated Fatty Acids on Limitless Replicative Potential of Tumours}

Growth signal autonomy, insensitivity to antigrowth signals, and apoptotic evasion alone do not lead to expansive tumour 
growth because cells have the capacity for senescence, an intrinsic property that limits multiplication [39, 104]. Senescence can be circumvented by DNA damage and disabling tumour suppressor genes such as $\mathrm{p} 53$ and $\mathrm{pRb}$, which eventually leads to immortalisation or the ability to multiply without limit [105].

7.1. In Vitro Evidence. AA may promote tumour growth and replication via activation of protein kinase $\mathrm{C}$ stimulating mitosis [106]. Studies in colonocytes and JB6 cells-mouse epidermal cells-have shown that growth promotion via the transcription factors RAS and AP1 is reduced by $n-3$ PUFAs $[107,108]$. The second messengers of AA metabolism with COX and LOX also stimulate mitosis. Conversely EPA derived metabolites of COX and LOX have been shown to decrease growth of human breast cancer cell lines [42].

7.2. In Vivo Evidence. Numerous animal study models in colon cancer have demonstrated that n-3 PUFA supplementation leads to tumour growth suppression [68, 109-115].

It had been demonstrated in the rat colon that n-3 PUFAs reduced k-RAS mutations and decreased membrane RAS expression [116] and it has been suggested that this indicates that n-3 PUFAs may protect against colon carcinogenesis by decreasing DNA adduct formation and/or enhancing DNA repair [117]. In the study already discussed by Hong they also showed that there was a reduction in DNA adduct formation [99]. Reddy showed that initiation of experimentally induced colon cancer was reduced by the protective effect of n-3 PUFAs [118].

In xenografted rats carrying neuroblastoma tumours, Gleissman demonstrated that DHA-enriched diet prior to tumour cell injection delayed tumour formation and prevented tumour establishment [119]. In the same study Gleissman investigated the effect of DHA as a therapeutic agent in rats who had established tumours. Tumours in animals receiving high dose DHA showed partial response compared to animals receiving low dose DHA or control that showed stable disease and progressive disease, respectively [119].

Another therapeutic study performed in nude mice xenografted with BxPC-3 pancreatic cancer cells showed tumour inhibition by DHA. Interestingly the inhibition was increased in another group where DHA was combined with curcumin [120].

\section{Effects of Omega-3 Polyunsaturated Fatty Acids on Sustained Angiogenesis}

For a tumour to grow beyond $2 \mathrm{~mm}$, angiogenesis and neovascular formation are required. The ability to induce and sustain angiogenesis from vascular quiescence is controlled by the "angiogenic switch." Tumors appear to activate the angiogenic switch by changing the balance of angiogenesis inducers and countervailing inhibitors [121]. This is seen with increased production, expression, and signal transduction of pro-angiogenic factors such as vascular endothelial growth factor (VEGF). n-3 PUFAs have been shown to have a profound effect on angiogenesis [122].
8.1. In Vitro Evidence. n-3 PUFAs have been shown to decrease sprouting angiogenesis by suppressing VEGFstimulated endothelial cell proliferation, migration, and tube formation [123-125]. Tsuzuki and colleagues treated human umbilical vein endothelial cells with conjugated EPA and demonstrated that a reduction in sprouting angiogenesis tube formation and endothelial cell migration [123] was also seen in bovine aortic endothelial cells pre-treated with DPA. VEGF-Receptor (VEGF-R) 2 expression was also found to be suppressed [124]. The reduction in endothelial cell proliferation in response to EPA was shown to be dose dependant in bovine carotid artery endothelial cells [125]. The study by Yang et al. also elicited a dose dependant decrease in VEGF-1 (FlK-1) expression [125]. A reduction in VEGF/VEGF-R binding has also been demonstrated by Yuan et al. using an n-3 PUFA rich shark oil [126].

n-3 PUFAs also have stark effects on numerous other mediators involved in angiogenesis. Platelet derived growth factors (PDGF) play an important role in angiogenesis by stimulating fibroblast and vascular smooth muscle cell motility and acting as a chemo-attractant [127, 128]. As early as 1988 Fox and DiCorleto showed that in vitro production of PDGF was inhibited by n-3 PUFAs [129]. Investigating the effects of EPA and DHA on PDGF signal transduction Terano and colleagues demonstrated that EPA inhibited PDGF binding to its receptor and suppressed c-fos mRNA expression, a gene involved in receptor signal transduction. These effects led to inhibition of smooth muscle proliferation a prerequisite for angiogenesis [130].

As previously discussed PGE2 is formed from AA, catalysed by COX-2. There is well-defined link between E series prostaglandins and carcinogenesis [131]. Decreased levels of VEGF, COX-2, and PGE2 have been demonstrated in HT-29 colon cancer cell lines when cultured in vitro with EPA and DHA [112] and a synergistic inhibitory effect of n-3 PUFAs and COX-2 inhibitors on growth of human colon cancer cell lines has been shown $[60,132]$.

Nitric oxide (NO) promotes endothelial cell survival and proliferation and inhibits apoptosis [133, 134]. NO and COX-2 also regulate VEGF-mediated angiogenesis [135137]. Inducible nitric oxide synthase (iNOS) stimulates NO production [136].

DHA has been demonstrated to inhibit NO production and iNOS expression in murine macrophages [63, 64, 138140] and downregulate $\mathrm{NO}$ and nuclear factor kappa beta (NFKB) in human colon cancer cell lines [141].

In the study previously discussed by Tsuzuki et al., they also demonstrated that production of matrix metalloproteinases (MMP) 2 and 9-proteases which play a role in basement membrane proteolysis in the 3rd stage of sprouting angiogenesis-in human endothelial cells was inhibited by EPA [123].

It has also been demonstrated that DHA inhibits Beta-catenin-a transcriptional regulator of angiogenesisproduction in colon cancer cells [142].

8.2. In Vivo Evidence. In a study where Fischer 344 rats were implanted with fibrosarcomas, the group with diets supplemented with EPA had tumours with significantly lower 


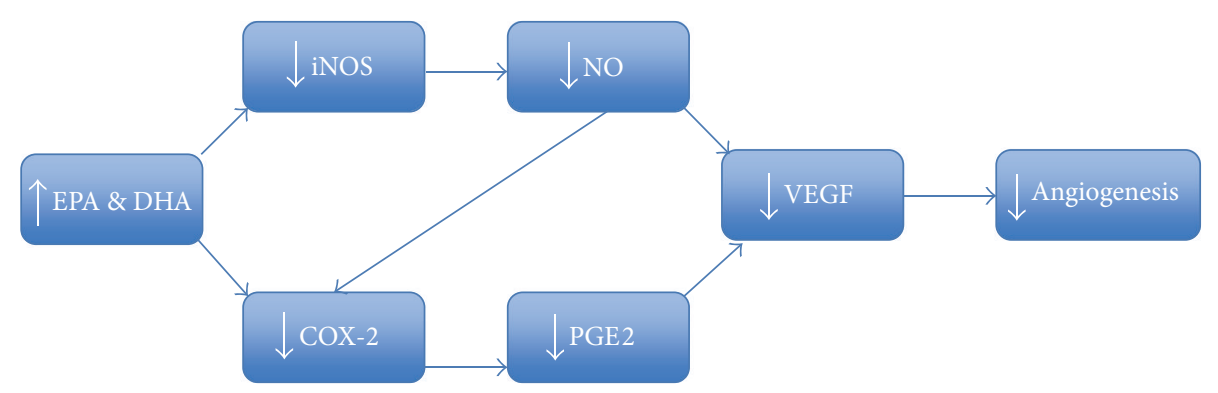

FIGURE 3: Pathways leading to the anti-angiogeneis effect of DHA and EPA.

tumour volume and decreased VEGF-alpha mRNA levels [143].

A study in nude mice supplemented with n-3 PUFA undergoing implantation of human colorectal carcinomas showed that tumour expression of VEGF, COX-2, and PGE2 was decreased compared to control [112]. Benefits were also seen in nude mice transplanted with breast carcinoma. Breast tumours in mice feed diets high in EPA and DHA had lower tumour microvessel density and VEGF levels compared to controls $[144,145]$.

Induction of vascular smooth muscle cell migration by PDGF, required for angiogenesis, is inhibited by EPA and DHA in vivo [130]. Several other small animal models have demonstrated that n-3 PUFA enriched diets inhibit COX2 and PGE2 production [146] and reduced HT-29 colon cancer cell tumour growth and microvessel density after implantation into nude mice [112].

Factors such as PGE2, NO, COX-2, and NFKB have well-documented roles in both the inflammatory and angiogenic cascades with significant cross-relation in both pathways. This demonstrates the potential for n-3 FAs as antiangiogenic agents via inhibition of these factors and others including VEGF and PDGF (Figure 3).

\section{Effects of Omega-3 Polyunsaturated Fatty Acids on Tumour Tissue Invasion and Metastasis}

Metastases are the cause of $90 \%$ of human cancer related deaths [147]. Like the formation of the initial tumour the above 5 characteristics are required for metastasis formation. Metastasis and tissue invasion also require loss of cell-cell adhesion-regulated by cell adhesion molecules (CAMs) - and cell-ECM interactions-regulated by integrins $[39,148]$. Ecadherin, a CAM, is lost in the majority of epithelial cancers, which enables invasion and metastases [149]. Once at a new site tumour cells then shift the expression of integrins to facilitate preferential cell binding to allow the tumour to "seed" leading to subsequent distant growth.

9.1. In Vitro Evidence. DHA has been shown to reduce the induction of monocyte rolling, adhesion, and transmigration controlled by TNF $\alpha$ [150].

As previously discussed NO increases tumour growth and angiogenesis [61, 62, 151-153]. NO also plays an important role in tumour cell migration, which may be decreased by EPA and DHA supplementation due to suppression of tumour derived NO production $[63,64]$.

Cell-cell adhesion is modulated by DHA via down regulation of Rho GTPase, which inhibits cytoskeleton reorganisation [154], and reduction in ICAM-1 and VCAM-1 expression [155].

9.2. In Vivo Evidence. Again the COX-2 pathway plays an important role in each of the tumour development pathways. COX-2 reduces cell-cell and cell-matrix interactions leading to increased progression and metastases of gastric carcinoma $[156,157]$. COX-2 inhibition has been shown to reduce invasiveness and depress metastases of gastric cancer in various animal models [67]. A xenograft animal model showed inhibition of tumour cell growth and invasion by n3 PUFAs associated with decreased COX-2 and PGE2 levels [70]. n-3 PUFAs may act as a natural COX inhibitor [158]. Despite the wealth of evidence of the beneficial anti-tumour effects of DHA and EPA via downregulation of the COX-2 pathway a study by Boudreau has suggested that there are also COX-2 independent methods of protective action. In a colon cancer xenograft model, tumour formation was inhibited by n-3 PUFA supplementation in both COX-2 deficient and COX-2 overexpressing tumours [111].

Inhibition of metastases by n-3 PUFA enriched diets was demonstrated in both mouse and rat $[159,160]$ models of colorectal cancer. EPA and DHA have also been shown to suppress development of lung metastases due to reduced 72$\mathrm{kDa}$ type IV collagenase gelatinolytic activity [161].

There is a large and growing body of evidence from laboratory-based studies that n-3 PUFAs have a marked beneficial effect on the hallmarks of cancer. However do these mechanistic studies translate into a clinical benefit?

\section{Effects of Omega-3 Polyunsaturated Fatty Acids on Tumourigenesis in Humans}

As well as the cellular mechanisms described in the in-vitro and in-vivo studies above, epidaemiological observations also appeared to suggest a benefit of n-3 PUFA in cancer prevention in humans. An example is an observational study in Inuits-Inuits have DHA levels several times higher than Caucasians [162] — which has demonstrated significantly lower levels of childhood cancer occurrence, particularly 
neuroblastoma-tenfold decrease-and Hodgkin lymphoma $[92,163]$.

However, a systematic review of the "Effects of omega3 fatty acids on cancer risk" by MacLean et al. reviewed 38 articles published from 1966 to 2005 which included 65 estimates of association calculated over 20 differing cohorts for 11 different cancer types concluded that only 10 were statistically significant and that the body of literature does not provide evidence to suggest a significant association between n-3 PUFA and cancer incidence. They also stated that dietary supplementation with n-3 PUFAs is unlikely to prevent cancer [164]. Chen et al. raised concerns with the systematic review [165]. The studies included in this systematic review did not formally measure FA consumption-food frequency questionnaires and dietary records were used which correlate poorly with direct PUFA measurement [166] - The studies included in this systematic review did not formally measure FA consumption, they used food frequency questionnaires and dietary records, which correlate poorly with direct PUFA measurement [166] and do not differentiate between the source of FO consumption [165].

Animal data-some of which has been discussed aboveis an invaluable tool for mechanistic studies and the models can closely mimic the clinical course of cancer progressions $[165,167,168]$. However the translation of animal data into the clinical arena is difficult due to the higher amounts of n-3 PUFAs used in relation to fat intake and percentage weight [164]. Inherent to the majority of animal studies is the use of high levels of dietary constituents [117] with n-3 PUFA intake between 18 and $48 \%$ of daily energy compared to $4-10 \%$ in human population based studies [169]. This is likely to be one of the reasons that only weak associations of PUFA intake and cancer are found in population-based studies [117]. Extrapolation of findings is also confounded by poor descriptions of experimental conditions and dose and purity of n-3 PUFA supplementation $[164,170]$.

However, a role is potentially being developed for $n-3$ PUFA in combination with current chemotherapeutic agents to augment their action [171]. Animal models have shown that the efficiency of doxorubicin [172] and mitomycin C [173] in inhibiting tumor growth and the inhibitory effect of tamoxifen in estrogen-dependent xenografts [174] are enhanced when combined with n-3 PUFA-enriched diets.

DHA supplementation with concurrent cytotoxic drug treatment is potentially a way in which to clinically utilise DHA in cancer treatment. DHA in combination with doxorubicin, irinotecan, cisplatin, melphalan, and vincristine on neuroblastoma cell survival shows additive or synergistic interactions $[85,92]$.

A therapeutic study in breast cancer patients where DHA was combined with the chemotherapeutic drugs epirubicin, cyclophosphamide, and 5-fluorouracil showed delayed time to tumour progression and longer overall survival. However these findings were only observed when patients were stratified into 2 groups of either high or low incorporation of DHA into plasma and erythrocytes. Patients who had high incorporation of DHA into plasma and erythrocytes benefitted compared to those who had low level DHA incorporation [175]. This observation correlates well with other studies showing that DHA incorporation differs between individuals due to dissimilar rates of metabolism, enzymatic activity, background diet, age, and sex [92, 176-178]. This is likely to be a recurrent problem in studies using oral n-3 PUFA supplementation.

\section{Discussion}

In the last decade there has been a growing interest in the role of FAs, especially PUFAs, in cancer development and progression. As discussed the link between FAs and cancer may relate to the synthesis of eicosanoids, which have wideranging diverse effects at a cellular level. There are currently several ongoing clinical trials to assess this, where n-3 PUFAs are being tested for cancer prevention, support, or therapy [158], but initial evidence suggests that researchers do not seem to be translating the profoundly beneficial results seen in the laboratory to the bedside. This is potentially due to the way in which n-3 PUFAs are being supplemented and we need to think about novel ways of overcoming the difficulties faced with FO supplementation to assess the true benefit of n-3 PUFAs in the fight against cancer. Maybe we also need to explore the broader therapeutic benefits of FO supplementation on areas such as cancer cachexia and aiding treatment tolerance as recently suggested by Murphy et al. [179]. However, ongoing and future clinical trials using intravenous n-3 PUFA infusions in cancer therapy are eagerly awaited.

\section{Acknowledgment}

A. R. Dennison, M. S. Metcalfe, J. A. Stephenson, O. Al-Taan, and A. Arshad have received educational travelling grants from B. Braun Melsungen.

\section{References}

[1] W. M. N. Ratnayake and C. Galli, "Fat and fatty acid terminology, methods of analysis and fat digestion and metabolism: a background review paper," Annals of Nutrition and Metabolism, vol. 55, no. 1-3, pp. 8-43, 2009.

[2] B. Burlingame, C. Nishida, R. Uauy, and R. Weisell, "Fats and fatty acids in human nutrition: introduction," Annals of Nutrition and Metabolism, vol. 55, no. 1-3, pp. 5-7, 2009.

[3] S. A. Moore, E. Hurt, E. Yoder, H. Sprecher, and A. A. Spector, "Docosahexaenoic acid synthesis in human skin fibroblasts involves peroxisomal retroconversion of tetracosahexaenoic acid," Journal of Lipid Research, vol. 36, no. 11, pp. 2433-2443, 1995.

[4] H. Sprecher, "The roles of anabolic and catabolic reactions in the synthesis and recycling of polyunsaturated fatty acids," Prostaglandins Leukotrienes and Essential Fatty Acids, vol. 67, no. 2-3, pp. 79-83, 2002.

[5] B. Lands, "A critique of paradoxes in current advice on dietary lipids," Progress in Lipid Research, vol. 47, no. 2, pp. 77-106, 2008.

[6] G. C. Burdge and P. C. Calder, "Conversion of $\alpha$-linolenic acid to longer-chain polyunsaturated fatty acids in human adults," Reproduction Nutrition Development, vol. 45, no. 5, pp. 581-597, 2005. 
[7] R. G. Ackman, "Fatty acids in fish and shellfish," in Fatty Acids in Foods and Their Health Implications, C. K. Chow, Ed., pp. 155185, CRC Press, London, UK, 2008.

[8] J. T. Brenna, "Efficiency of conversion alpha-linolenic acid to long chain n-3 fatty acids in man," Current Opinion in Clinical Nutrition \& Metabolic Care, vol. 5, pp. 127-132, 2002.

[9] P. L. L. Goyens, M. E. Spilker, P. L. Zock, M. B. Katan, and R. P. Mensink, "Conversion of $\alpha$-linolenic acid in humans is influenced by the absolute amounts of $\alpha$-linolenic acid and linoleic acid in the diet and not by their ratio," American Journal of Clinical Nutrition, vol. 84, no. 1, pp. 44-53, 2006.

[10] A. J. Sinclair, N. M. Attar-Bashi, and D. Lib, "What is the role of $\alpha$ t-linolenic acid for mammals?” Lipids, vol. 37, no. 12, pp. 11131123, 2003.

[11] B. Corridan and A. Wilson, "Health effects of $n-3$ polyunsaturated fatty acids," in Encyclopedia of Human Nutrition, J. Strain, M. Sadler, and B. Caballero, Eds., vol. 1, pp. 757-769, Academic Press, New York, NY, USA, 1998.

[12] C. E. Eberhart and R. N. Dubois, "Eicosanoids and the gastrointestinal tract," Gastroenterology, vol. 109, no. 1, pp. 285-301, 1995.

[13] C. E. Roynette, P. C. Calder, Y. M. Dupertuis, and C. Pichard, "n-3 polyunsaturated fatty acids and colon cancer prevention," Clinical Nutrition, vol. 23, no. 2, pp. 139-151, 2004.

[14] P. Yaqoob, H. S. Pala, M. Cortina-Borja, E. A. Newsholme, and P. C. Calder, "Encapsulated fish oil enriched in $\alpha$-tocopherol alters plasma phospholipid and mononuclear cell fatty acid compositions but not mononuclear cell functions," European Journal of Clinical Investigation, vol. 30, no. 3, pp. 260-274, 2000.

[15] C. N. Serhan, S. Hong, K. Gronert et al., "Resolvins: a family of bioactive products of omega-3 fatty acid transformation circuits initiated by aspirin treatment that counter proinflammation signals," Journal of Experimental Medicine, vol. 196, no. 8, pp. 1025-1037, 2002.

[16] J. Lee and D. H. Hwang, "Dietary fatty acids and eicosanoids," in Fatty Acids in Foods and Their Health Implications, C. K. Chow, Ed., pp. 713-739, CRC Press, London, UK, 2008.

[17] N. G. Bazan, "Omega-3 fatty acids, pro-inflammatory signaling and neuroprotection," Current Opinion in Clinical Nutrition \& Metabolic Care, vol. 10, pp. 136-141, 2007.

[18] P. C. Calder, "Polyunsaturated fatty acids and inflammation," Prostaglandins Leukotrienes and Essential Fatty Acids, vol. 75, pp. 197-202, 2006.

[19] P. C. Calder, "n-3 polyuusaturated fatty acids, inflammation, and inflammatory diseases," The American Journal of Clinical Nutrition, vol. 83, supplement 6, pp. 1505s-1519s, 2006.

[20] G. E. Caughey, E. Mantzioris, R. A. Gibson, L. G. Cleland, and M. J. James, "The effect on human tumor necrosis factor $\alpha$ and interleukin $1 \beta$ production of diets enriched in $n-3$ fatty acids from vegetable oil or fish oil," American Journal of Clinical Nutrition, vol. 63, no. 1, pp. 116-122, 1996.

[21] R. I. Sperling, A. I. Benincaso, C. T. Knoell, J. K. Larkin, K. F. Austen, and D. R. Robinson, "Dietary $\omega-3$ polyunsaturated fatty acids inhibit phosphoinositide formation and chemotaxis in neutrophils," Journal of Clinical Investigation, vol. 91, no. 2, pp. 651-660, 1993.

[22] P. C. Calder, "Dietary modification of inflammation with lipids," Proceedings of the Nutrition Society, vol. 61, pp. 345-358, 2002.

[23] S. A. Schwartz, A. Hernandez, and B. M. Evers, "The role of NF-kappaB/IkappaB proteins in cancer: implications for novel treatment strategies," Surgical Oncology, vol. 8, no. 3, pp. 143$153,1999$.
[24] V. M. Barbosa, E. A. Miles, C. Calhau, E. Lafuente, and P. C. Calder, "Effects of a fish oil containing lipid emulsion on plasma phospholipid fatty acids, inflammatory markers, and clinical outcomes in septic patients: a randomized, controlled clinical trial," Critical Care, vol. 14, no. 1, article R5, 2010.

[25] P. C. Calder, "Symposium 4: hot topics in parenteral nutrition Rationale for using new lipid emulsions in parenteral nutrition and a review of the trials performed in adults," Proceedings of the Nutrition Society, vol. 68, no. 3, pp. 252-260, 2009.

[26] P. C. Calder, G. L. Jensen, B. V. Koletzko, P. Singer, and G. J. A. Wanten, "Lipid emulsions in parenteral nutrition of intensive care patients: current thinking and future directions," Intensive Care Medicine, vol. 36, no. 5, pp. 735-749, 2010.

[27] S. Friesecke, C. Lotze, J. Köhler, A. Heinrich, S. B. Felix, and P. Abel, "Fish oil supplementation in the parenteral nutrition of critically ill medical patients: a randomised controlled trial," Intensive Care Medicine, vol. 34, no. 8, pp. 1411-1420, 2008.

[28] H. Grimm, N. Mertes, C. Goeters et al., "Improved fatty acid and leukotriene pattern with a novel lipid emulsion in surgical patients," European Journal of Nutrition, vol. 45, no. 1, pp. 55-60, 2006.

[29] A. R. Heller, T. Rössel, B. Gottschlich et al., “Omega-3 fatty acids improve liver and pancreas function in postoperative cancer patients," International Journal of Cancer, vol. 111, no. 4, pp. 611616, 2004.

[30] A. R. Heller, S. Rössler, R. J. Litz et al., "Omega-3 fatty acids improve the diagnosis-related clinical outcome," Critical Care Medicine, vol. 34, pp. 972-979, 2006.

[31] M. M. Berger, L. Tappy, J. P. Revelly et al., "Fish oil after abdominal aorta aneurysm surgery," European Journal of Clinical Nutrition, vol. 62, no. 9, pp. 1116-1122, 2008.

[32] H. Grimm, "A balanced lipid emulsion-a new concept in parenteral nutrition," Clinical Nutrition, vol. 1, no. 3, pp. 25-30, 2005.

[33] M. Köller, M. Senkal, M. Kemen, W. König, V. Zumtobel, and G. Muhr, "Impact of omega-3 fatty acid enriched TPN on leukotriene synthesis by leukocytes after major surgery," Clinical Nutrition, vol. 22, no. 1, pp. 59-64, 2003.

[34] B. J. Morlion, E. Torwesten, H. Lessire et al., "The effect of parenteral fish oil on leukocyte membrane fatty acid composition and leukotriene-synthesizing capacity in patients with postoperative trauma," Metabolism: Clinical and Experimental, vol. 45, no. 10, pp. 1208-1213, 1996.

[35] K. Mayer, S. Gokorsch, C. Fegbeutel et al., "Parenteral nutrition with fish oil modulates cytokine response in patients with sepsis," American Journal of Respiratory and Critical Care Medicine, vol. 167, no. 10, pp. 1321-1328, 2003.

[36] E. Tsekos, C. Reuter, P. Stehle, and G. Boeden, "Perioperative administration of parenteral fish oil supplements in a routine clinical setting improves patient outcome after major abdominal surgery," Clinical Nutrition, vol. 23, no. 3, pp. 325-330, 2004.

[37] G. Weiss, F. Meyer, B. Matthies, M. Pross, W. Koenig, and H. Lippert, "Immunomodulation by perioperative administration of n-3 fatty acids," British Journal of Nutrition, vol. 87, no. 1, pp. S89-S94, 2002.

[38] M. W. Wichmann, P. Thul, H. D. Czarnetzki, B. J. Morlion, M. Kemen, and K. W. Jauch, "Evaluation of clinical safety and beneficial effects of a fish oil containing lipid emulsion (Lipoplus, MLF541): data from a prospective, randomized, multicenter trial," Critical Care Medicine, vol. 35, no. 3, pp. 700706, 2007. 
[39] D. Hanahan and R. A. Weinberg, “The hallmarks of cancer," Cell, vol. 100, no. 1, pp. 57-70, 2000.

[40] D. Hanahan and R. A. Weinberg, "Hallmarks of cancer: the next generation," Cell, vol. 144, no. 5, pp. 646-674, 2011.

[41] S. H. Abou-El-Ala, K. W. Prasse, R. L. Farrell, R. W. Carroll, A. E. Wade, and O. R. Bunce, "Effects of D,L2-difluoromethylornithine and indomethacin on mammary tumor promotion in rats fed high n-3 and/or n-6 fat diets," Cancer Research, vol. 49, no. 6, pp. 1434-1440, 1989.

[42] D. P. Rose and J. M. Connolly, "Effects of fatty acids and inhibitors of eicosanoid synthesis on the growth of a human breast cancer cell line in culture," Cancer Research, vol. 50, no. 22, pp. 7139-7144, 1990.

[43] M. D. Brown, C. A. Hart, E. Gazi, S. Bagley, and N. W. Clarke, "Promotion of prostatic metastatic migration towards human bone marrow stoma by Omega 6 and its inhibition by Omega 3 PUFAs," British Journal of Cancer, vol. 94, no. 6, pp. 842-853, 2006.

[44] C. N. Serhan, M. Arita, S. Hong, and K. Gotlinger, "Resolvins, docosatrienes, and neuroprotectins, novel omega-3-derived mediators, and their endogenous aspirin-triggered epimers," Lipids, vol. 39, no. 11, pp. 1125-1132, 2004.

[45] C. N. Serhan and J. Savill, "Resolution of inflammation: the beginning programs the end," Nature Immunology, vol. 6, no. 12, pp. 1191-1197, 2005.

[46] M. Karin, "Nuclear factor-kappaB in cancer development and progression," Nature, vol. 441, pp. 431-436, 2006.

[47] L. M. Coussens and Z. Werb, "Inflammation and cancer," Nature, vol. 420, no. 6917, pp. 860-867, 2002.

[48] H. Clevers, "At the crossroads of inflammation and cancer," Cell, vol. 118, no. 6, pp. 671-674, 2004.

[49] I. M. Berquin, Y. Min, R. Wu et al., "Modulation of prostate cancer genetic risk by omega-3 and omega- 6 fatty acids," Journal of Clinical Investigation, vol. 117, pp. 1866-1875, 2007.

[50] P. Fedi, S. R. Tronick, and S. A. Aaronson, "Growth factors," in Cancer Medicine, J. F. Holland, R. C. Bast, D. L. Morton, E. Frei, D. W. Kufe, and R. R. Weichselbaum, Eds., pp. 41-64, Williams and Wilkins, Baltimore, Md, USA, 1999.

[51] D. J. Slamon, G. M. Clark, S. G. Wong, W. J. Levin, A. Ullrich, and W. L. McGuire, "Human breast cancer: correlation of relapse and survival with amplification of the HER-2/neu oncogene," Science, vol. 235, no. 4785, pp. 177-182, 1987.

[52] M. E. Lukashev and Z. Werb, "ECM signalling: orchestrating cell behaviour and misbehaviour," Trends in Cell Biology, vol. 8, no. 11, pp. 437-441, 1998.

[53] K. W. Kinzler and B. Vogelstein, "Lessons from hereditary colorectal cancer," Cell, vol. 87, no. 2, pp. 159-170, 1996.

[54] P. D. Schley, D. N. Brindley, and C. J. Field, “(n-3) PUFA alter raft lipid composition and decrease epidermal growth factor receptor levels in lipid rafts of human breast cancer cells," Journal of Nutrition, vol. 137, no. 3, pp. 548-553, 2007.

[55] B. S. Reddy, B. Simi, N. Patel, C. Aliaga, and C. V. Rao, "Effect of amount and types of dietary fat on intestinal bacterial $7 \alpha$ dehydroxylase and phosphatidylinositol-specific phospholipase $\mathrm{C}$ and colonic mucosal diacylglycerol kinase and PKC activities during different stages of colon tumor promotion," Cancer Research, vol. 56, no. 10, pp. 2314-2320, 1996.

[56] M. F. McCarty, "Fish oil may impede tumour angiogenesis and invasiveness by down-regulating protein kinase $\mathrm{C}$ and modulating eicosanoid production," Medical Hypotheses, vol. 46, no. 2, pp. 107-115, 1996.
[57] J. Singh, R. Hamid, and B. S. Reddy, "Dietary fat and colon cancer: modulating effect of types and amount of dietary fat on ras-p21 function during promotion and progression stages of colon cancer," Cancer Research, vol. 57, no. 2, pp. 253-258, 1997.

[58] T. E. Novak, T. A. Babcock, D. H. Jho, W. S. Helton, and N. J. Espat, "NF- $\kappa$ B inhibition by $\omega-3$ fatty acids modulates LPS-stimulated macrophage TNF- $\alpha$-transcription," American Journal of Physiology, vol. 284, no. 1, pp. L84-L89, 2003.

[59] N. K. Narayanan, B. A. Narayanan, M. Bosland, M. S. Condon, and D. Nargi, "Docosahexaenoic acid in combination with celecoxib modulates HSP70 and p53 proteins in prostate cancer cells," International Journal of Cancer, vol. 119, no. 7, pp. 15861598, 2006.

[60] N. K. Narayanan, B. A. Narayanan, and B. S. Reddy, "A combination of docosahexaenoic acid and celecoxib prevents prostate cancer cell growth in vitro and is associated with modulation of nuclear factor-kappaB, and steroid hormone receptors," International Journal of Oncology, vol. 26, no. 3, pp. 785-792, 2005.

[61] P. K. Lala and C. Chakraborty, "Role of nitric oxide in carcinogenesis and tumour progression," Lancet Oncology, vol. 2, no. 3, pp. 149-156, 2001.

[62] D. A. Wink, Y. Vodovotz, J. Laval, F. Laval, M. W. Dewhirst, and J. B. Mitchell, "The multifaceted roles of nitric oxide in cancer," Carcinogenesis, vol. 19, no. 5, pp. 711-721, 1998.

[63] T. Ohata, K. Fukuda, M. Takahashi, T. Sugimura, and K. Wakabayashi, "Suppression of nitric oxideproduction in lipopolysaccharide-stimulated macrophage cells by omega 3 polyunsaturated fatty acids," Japanese Journal of Cancer Research, vol. 88, no. 3, pp. 234-237, 1997.

[64] S. C. Larsson, M. Kumlin, M. Ingelman-Sundberg, and A. Wolk, "Dietary long-chain n-3 fatty acids for the prevention of cancer: a review of potential mechanisms," The American Journal of Clinical Nutrition, vol. 79, no. 6, pp. 935-945, 2004.

[65] E. J. Kim, W. Y. Kim, Y. H. Kang, Y. L. Ha, L. A. Bach, and J. H. Y. Park, "Inhibition of Caco-2 cell proliferation by (n-3) fatty acids: possible mediation by increased secretion of insulin-like growth factor binding protein-6," Nutrition Research, vol. 20, no. 10, pp. 1409-1421, 2000.

[66] J. Singh, R. Hamid, and B. S. Reddy, "Dietary fat and colon cancer: modulation of cyclooxygenase- 2 by types and amount of dietary fat during the postinitiation stage of colon carcinogenesis," Cancer Research, vol. 57, no. 16, pp. 3465-3470, 1997.

[67] S. L. Fu, Y. L. Wu, Y. P. Zhang, M. M. Qiao, and Y. Chen, "Anticancer effects of COX-2 inhibitors and their correlation with angiogenesis and invasion in gastric cancer," World Journal of Gastroenterology, vol. 10, no. 13, pp. 1971-1974, 2004.

[68] M. Takahashi, M. Fukutake, T. Isoi et al., "Suppression of azoxymethane-induced rat colon carcinoma development by a fish oil component, docosahexaenoic acid (DHA)," Carcinogenesis, vol. 18, no. 7, pp. 1337-1342, 1997.

[69] C. V. Rao, Y. Hirose, C. Indranie, and B. S. Reddy, "Modulation of experimental colon tumorigenesis by types and amounts of dietary fatty acids," Cancer Research, vol. 61, no. 5, pp. 1927-1933, 2001.

[70] N. Kobayashi, R. J. Barnard, S. M. Henning et al., "Effect of altering dietary omega-6/ omega-3 fatty acid ratios on prostate cancer membrane composition, cyclooxygenase-2, and prostaglandin E2," Clinical Cancer Research, vol. 12, pp. 4662 4670, 2006.

[71] Y. H. Jiang, J. R. Lupton, and R. S. Chapkin, "Dietary fish oil blocks carcinogen-induced down-regulation of colonic protein 
kinase C isozymes," Carcinogenesis, vol. 18, no. 2, pp. 351-357, 1997.

[72] Y. Gökmen-Polar, N. R. Murray, M. A. Velasco, Z. Gatalica, and A. P. Fields, "Elevated protein kinase $\mathrm{C} \beta \mathrm{II}$ is an early promotive event in colon carcinogenesis," Cancer Research, vol. 61, no. 4, pp. 1375-1381, 2001.

[73] N. R. Murray, L. A. Davidson, R. S. Chapkin, W. C. Gustafson, D. G. Schattenberg, and A. P. Fields, "Overexpression of protein kinase $\mathrm{C} \beta(\mathrm{II})$ induces colonic hyperproliferation and increased sensitivity to colon carcinogenesis," Journal of Cell Biology, vol. 145, no. 4, pp. 699-711, 1999.

[74] N. R. Murray, C. Weems, L. Chen et al., "Protein kinase C betaII and TGFbetaRII in omega-3 fatty acid mediated inhibition of colon carcinogenesis," The Journal of Cell Biology, vol. 157, pp. 915-920, 2002.

[75] S. Sauma, Y. Zhongfa, S. Ohno, and E. Friedman, "Protein kinase $C \beta 1$ and protein kinase $C \beta 2$ activate p57 mitogenactivated protein kinase and block differentiation in colon carcinoma cells," Cell Growth and Differentiation, vol. 7, no. 5, pp. 587-594, 1996.

[76] M. L. Saxon, X. Zhao, and J. D. Black, "Activation of protein kinase $\mathrm{C}$ isozymes is associated with post-mitotic events in intestinal epithelial cells in situ," Journal of Cell Biology, vol. 126, no. 3, pp. 747-763, 1994.

[77] L. A. Davidson, R. E. Brown, W. C. L. Chang et al., "Morphodensitometric analysis of protein kinase $\mathrm{C} \beta(\mathrm{II})$ expression in rat colon: modulation by diet and relation to in situ cell proliferation and apoptosis," Carcinogenesis, vol. 21, no. 8, pp. 1513-1519, 2000.

[78] V. Mengeaud, J. L. Nano, S. Fournel, and P. Rampal, "Effects of eicosapentaenoic acid, gamma-linolenic acid and prostaglandin E1 on three human colon carcinoma cell lines," Prostaglandins Leukotrienes and Essential Fatty Acids, vol. 47, no. 4, pp. 313-319, 1992.

[79] W. S. Tsai, H. Nagawa, S. Kaizaki, T. Tsuruo, and T. Muto, "Inhibitory effects of n-3 polyunsaturated fatty acids on sigmoid colon cancer transformants," Journal of Gastroenterology, vol. 33, no. 2, pp. 206-212, 1998.

[80] Z. Y. Chen and N. W. Istfan, "Docosahexaenoic acid is a potent inducer of apoptosis in HT-29 colon cancer cells," Prostaglandins Leukotrienes and Essential Fatty Acids, vol. 63, no. 5, pp. 301-308, 2000.

[81] R. G. Clarke, E. K. Lund, P. Latham, A. C. Pinder, and I. T. Johnson, "Effect of eicosapentaenoic acid on the proliferation and incidence of apoptosis in the colorectal cell line HT29," Lipids, vol. 34, pp. 1287-1295, 1999.

[82] P. Palozza, G. Calviello, N. Maggiano, P. Lanza, F. O. Ranelletti, and G. M. Bartoli, "Beta-carotene antagonizes the effects of eicosapentaenoic acid on cell growth and lipid peroxidation in WiDr adenocarcinoma cells," Free Radical Biology and Medicine, vol. 28, no. 2, pp. 228-234, 2000.

[83] M. L. Jourdan, K. Mahéo, A. Barascu et al., "Increased BRCA1 protein in mammary tumours of rats fed marine omega-3 fatty acids," Oncology Reports, vol. 17, no. 4, pp. 713-719, 2007.

[84] H. Gleissman, R. Yang, K. Martinod et al., "Docosahexaenoic acid metabolome in neural tumors: identification of cytotoxic intermediates," FASEB Journal, vol. 24, no. 3, pp. 906-915, 2010.

[85] M. Lindskog, H. Gleissman, F. Ponthan, J. Castro, P. Kogner, and J. I. Johnsen, "Neuroblastoma cell death in response to docosahexaenoic acid: sensitization to chemotherapy and arsenicinduced oxidative stress," International Journal of Cancer, vol. 118, no. 10, pp. 2584-2593, 2006.
[86] S. Serini, E. Piccioni, N. Merendino, and G. Calviello, "Dietary polyunsaturated fatty acids as inducers of apoptosis: implications for cancer," Apoptosis, vol. 14, no. 2, pp. 135-152, 2009.

[87] K. Arita, H. Kobuchi, T. Utsumi et al., "Mechanism of apoptosis in HL-60 cells induced by n-3 and n- 6 polyunsaturated fatty acids," Biochemical Pharmacology, vol. 62, no. 7, pp. 821-828, 2001.

[88] Y. Y. Fan, T. E. Spencer, N. Wang, M. P. Moyer, and R. S. Chapkin, "Chemopreventive n-3 fatty acids activate RXR $\alpha$ in colonocytes," Carcinogenesis, vol. 24, no. 9, pp. 1541-1548, 2003.

[89] C. Chambrier, J. P. Bastard, J. Rieusset et al., "Eicosapentaenoic acid induces mRNA expression of peroxisome proliferatoractivated receptor $\gamma$," Obesity Research, vol. 10, no. 6, pp. 518525, 2002.

[90] H. Zand, A. Rhimipour, M. Bakhshayesh, M. Shafiee, I. Nour Mohammadi, and S. Salimi, "Involvement of PPAR- $\gamma$ and p53 in DHA-induced apoptosis in Reh cells," Molecular and Cellular Biochemistry, vol. 304, no. 1-2, pp. 71-77, 2007.

[91] B. Sun, Y. L. Wu, S. N. Wang et al., "The effects of sulindac on induction of apoptosis and expression of cyclooxygenase-2 and Bcl-2 in human hepatocellular carcinoma cells," Zhonghua Xiaohua Zazhi, vol. 22, pp. 338-340, 2002.

[92] H. Gleissman, J. I. Johnsen, and P. Kogner, "Omega-3 fatty acids in cancer, the protectors of good and the killers of evil?" Experimental Cell Research, vol. 316, no. 8, pp. 1365-1373, 2010.

[93] G. Calviello, F. Di Nicuolo, S. Serini et al., "Docosahexaenoic acid enhances the susceptibility of human colorectal cancer cells to 5-fluorouracil," Cancer Chemotherapy and Pharmacology, vol. 55, no. 1, pp. 12-20, 2005.

[94] N. Danbara, T. Yuri, M. Tsujita-Kyutoku et al., "Conjugated docosahexaenoic acid is a potent inducer of cell cycle arrest and apoptosis and inhibits growth of colo 201 human colon cancer cells," Nutrition and Cancer, vol. 50, no. 1, pp. 71-79, 2004.

[95] L. C. M. Chiu and J. M. F. Wan, "Induction of apoptosis in HL-60 cells by eicosapentaenoic acid (EPA) is associated with downregulation of bcl-2 expression," Cancer Letters, vol. 145, no. 1-2, pp. 17-27, 1999.

[96] B. A. Narayanan, N. K. Narayanan, and B. S. Reddy, "Docosahexaenoic acid regulated genes and transcription factors inducing apoptosis in human colon cancer cells," International Journal of Oncology, vol. 19, pp. 1255-1262, 2001.

[97] T. Yamagami, C. D. Porada, R. S. Pardini, E. D. Zanjani, and G. Almeida-Porada, "Docosahexaenoic acid induces dose dependent cell death in an early undifferentiated subtype of acute myeloid leukemia cell line," Cancer Biology and Therapy, vol. 8, no. 4, pp. 331-337, 2009.

[98] M. Tsujii and R. N. DuBois, "Alterations in cellular adhesion and apoptosis in epithelial cells overexpressing prostaglandin endoperoxide synthase 2," Cell, vol. 83, no. 3, pp. 493-501, 1995.

[99] M. Y. Hong, J. R. Lupton, J. S. Morris et al., "Dietary fish oil reduces O6-methylguanine DNA adduct levels in rat colon in part by increasing apoptosis during tumor initiation," Cancer Epidemiology Biomarkers and Prevention, vol. 9, no. 8, pp. 819826, 2000.

[100] J. Zha, H. Harada, E. Yang, J. Jockel, and S. J. Korsmeyer, "Serine phosphorylation of death agonist BAD in response to survival factor results in binding to 14-3-3 not BCL-X(L)," Cell, vol. 87, no. 4, pp. 619-628, 1996.

[101] E. Yang, J. Zha, J. Jockel, L. H. Boise, C. B. Thompson, and S. J. Korsmeyer, "Bad, a heterodimeric partner for $\mathrm{Bcl}-\mathrm{x}(\mathrm{L})$, and Bcl-2, displaces Bax and promotes cell death," Cell, vol. 80, no. 2, pp. 285-291, 1995. 
[102] L. Del Peso, M. González-García, C. Page, R. Herrera, and G. Nuñez, "Interleukin-3-induced phosphorylation of BAD through the protein kinase Akt," Science, vol. 278, no. 5338, pp. 687-689, 1997.

[103] S. R. Datta, H. Dudek, T. Xu et al., "Akt phosphorylation of BAD couples survival signals to the cell-intrinsic death machinery," Cell, vol. 91, no. 2, pp. 231-241, 1997.

[104] L. Hayflick, "Mortality and immortality at the cellular level. A review," Biochemistry, vol. 62, no. 11, pp. 1180-1190, 1997.

[105] W. E. Wright, O. M. Pereira-Smith, and J. W. Shay, "Reversible cellular senescence: implications for immortalization of normal human diploid fibroblasts," Molecular and Cellular Biology, vol. 9, no. 7, pp. 3088-3092, 1989.

[106] G. C. Blobe, L. M. Obeid, and Y. A. Hannun, "Regulation of protein kinase $\mathrm{C}$ and role in cancer biology," Cancer and Metastasis Reviews, vol. 13, no. 3-4, pp. 411-431, 1994.

[107] E. D. Collett, L. A. Davidson, Y. Y. Fan, J. R. Lupton, and R. S. Chapkin, "n-6 and n-3 polyunsaturated fatty acids differentially modulate oncogenic Ras activation in colonocytes," American Journal of Physiology, vol. 280, no. 5, pp. C1066-C1075, 2001.

[108] G. Liu, D. M. Bibus, A. M. Bode, W. Y. Ma, R. T. Holman, and Z. Dong, "Omega 3 but not omega 6 fatty acids inhibit AP-1 activity and cell transformation in JB6 cells," Proceedings of the National Academy of Sciences of the United States of America, vol. 98, no. 13, pp. 7510-7515, 2001.

[109] F. Cannizzo Jr. and S. A. Broitman, "Postpromotional effects of dietary marine or safflower oils on large bowel or pulmonary implants of CT-26 in mice," Cancer Research, vol. 49, no. 15, pp. 4289-4294, 1989.

[110] J. E. Paulsen, I. K. Elvsaas, I. L. Steffensen, and J. Alexander, "A fish oil derived concentrate enriched in eicosapentaenoic and docosahexaenoic acid as ethyl ester suppresses the formation and growth of intestinal polyps in the Min mouse," Carcinogenesis, vol. 18, no. 10, pp. 1905-1910, 1997.

[111] M. D. Boudreau, K. H. Sohn, S. H. Rhee, S. W. Lee, J. D. Hunt, and D. H. Hwang, "Suppression of tumor cell growth both in nude mice and in culture by n-3 polyunsaturated fatty acids: mediation through cyclooxygenase-independent pathways," Cancer Research, vol. 61, no. 4, pp. 1386-1391, 2001.

[112] G. Calviello, F. Di Nicuolo, S. Gragnoli et al., "n-3 PUFAs reduce VEGF expression in human colon cancer cells modulating the COX-2/PGE2 induced ERK-1 and -2 and HIF- $1 \alpha$ induction pathway," Carcinogenesis, vol. 25, no. 12, pp. 2303-2310, 2004.

[113] B. S. Reddy and H. Maruyama, "Effect of dietary fish oil on azoxymethane-induced colon carcinogenesis in male F344 rats," Cancer Research, vol. 46, no. 7, pp. 3367-3370, 1986.

[114] T. Minoura, T. Takata, M. Sakaguchi et al., "Effect of dietary eicosapentaenoic acid on azoxymethane-induced colon carcinogenesis in rats," Cancer Research, vol. 48, no. 17, pp. 47904794, 1988.

[115] C. W. Hendrickse, M. R. B. Keighley, and J. P. Neoptolemos, "Dietary $\omega-3$ fats reduce proliferation and tumor yields at colorectal anastomosis in rats," Gastroenterology, vol. 109, no. 2, pp. 431-439, 1995.

[116] L. A. Davidson, J. L. Lupton, Y. H. Jiang, and R. S. Chapkin, "Carcinogen and dietary lipid regulate ras expression and localization in rat colon without affecting farnesylation kinetics," Carcinogenesis, vol. 20, no. 5, pp. 785-791, 1999.

[117] Y. E. M. Dommels, G. M. Alink, P. J. Van Bladeren, and B. Van Ommen, "Dietary n-6 and n-3 polyunsaturated fatty acids and colorectal carcinogenesis: results from cultured colon cells, animal models and human studies," Environmental Toxicology and Pharmacology, vol. 11, pp. 297-308, 2002.

[118] B. S. Reddy, C. Burill, and J. Rigotty, "Effect of diets high in $\omega$ 3 and $\omega-6$ fatty acids on initiation and postinitiation stages of colon carcinogenesis," Cancer Research, vol. 51, no. 2, pp. 487491, 1991.

[119] H. Gleissman, L. Segerström, M. Hamberg et al., "Omega-3 fatty acid supplementation delays the progression of neuroblastoma in vivo," International Journal of Cancer, vol. 128, no. 7, pp. 17031711, 2011.

[120] M. V. Swamy, B. Citineni, J. M. R. Patlolla, A. Mohammed, Y. Zhang, and C. V. Rao, "Prevention and treatment of pancreatic cancer by curcumin in combination with omega-3 fatty acids," Nutrition and Cancer, vol. 60, no. 1, pp. 81-89, 2008.

[121] D. Hanahan and J. Folkman, "Patterns and emerging mechanisms of the angiogenic switch during tumorigenesis," Cell, vol. 86, no. 3, pp. 353-364, 1996.

[122] L. Spencer, C. Mann, M. Metcalfe et al., "The effect of omega3 FAs on tumour angiogenesis and their therapeutic potential," European Journal of Cancer, vol. 45, no. 12, pp. 2077-2086, 2009.

[123] T. Tsuzuki, A. Shibata, Y. Kawakami, K. Nakagawa, and T. Miyazawa, "Conjugated eicosapentaenoic acid inhibits vascular endothelial growth factor-induced angiogenesis by suppressing the migration of human umbilical vein endothelial cells," Journal of Nutrition, vol. 137, no. 3, pp. 641-646, 2007.

[124] M. Tsuji, S. I. Murota, and I. Morita, "Docosapentaenoic acid $(22: 5, n-3)$ suppressed tube-forming activity in endothelial cells induced by vascular endothelial growth factor," Prostaglandins Leukotrienes and Essential Fatty Acids, vol. 68, no. 5, pp. 337342, 2003.

[125] S. P. Yang, I. Morita, and S. I. Murota, "Eicosapentaenoic acid attenuates vascular endothelial growth factor-induced proliferation via inhibiting flk-1 receptor expression in bovine carotid artery endothelial cells," Journal of Cellular Physiology, vol. 176, pp. 342-349, 1998.

[126] L. Yuan, M. Yoshida, and P. F. Davis, "Inhibition of proangiogenic factors by a lipid-rich shark extract," Journal of Medicinal Food, vol. 9, no. 3, pp. 300-306, 2006.

[127] R. Ross, J. Glomset, B. Kariya, and L. Harker, "A platelet dependent serum factor that stimulates the proliferation of arterial smooth muscle cells in vitro," Proceedings of the National Academy of Sciences of the United States of America, vol. 71, no. 4, pp. 1207-1210, 1974.

[128] C. H. Heldin and B. Westermark, "Mechanism of action and in vivo role of platelet-derived growth factor," Physiological Reviews, vol. 79, no. 4, pp. 1283-1316, 1999.

[129] P. L. Fox and P. E. DiCorleto, "Fish oils inhibit endothelial cell production of platelet-derived growth factor-like protein," Science, vol. 241, no. 4864, pp. 453-456, 1988.

[130] T. Terano, T. Shiina, and Y. Tamura, "Eicosapentaenoic acid suppressed the proliferation of vascular smooth muscle cells through modulation of various steps of growth signals," Lipids, vol. 31, no. 3, pp. S301-S304, 1996.

[131] R. Stein Werblowsky, "Prostaglandin and cancer," Oncology, vol. 30, no. 2, pp. 169-176, 1974.

[132] B. S. Reddy, J. M. Patlolla, B. Simi, S. H. Wang, and C. V. Rao, "Prevention of colon cancer by low doses of celecoxib, a cyclooxygenase inhibitor, administered in diet rich in $\omega-3$ polyunsaturated fatty acids," Cancer Research, vol. 65, no. 17, pp. 8022-8027, 2005. 
[133] S. Dimmeler, C. Hermann, J. Galle, and A. M. Zeiher, "Upregulation of superoxide dismutase and nitric oxide synthase mediates the apoptosis-suppressive effects of shear stress on endothelial cells," Arteriosclerosis, Thrombosis, and Vascular Biology, vol. 19, no. 3, pp. 656-664, 1999.

[134] L. Rössig, B. Fichtlscherer, K. Breitschopf et al., "Nitric oxide inhibits caspase-3 by S-nitrosation in vivo," Journal of Biological Chemistry, vol. 274, no. 11, pp. 6823-6826, 1999.

[135] F. Cianchi, C. Cortesini, P. Bechi et al., "Up-regulation of cyclooxygenase 2 gene expression correlates with tumor angiogenesis in human colorectal cancer," Gastroenterology, vol. 121, no. 6, pp. 1339-1347, 2001.

[136] F. Cianchi, C. Cortesini, O. Fantappiè et al., "Cyclooxygenase-2 activation mediates the proangiogenic effect of nitric oxide in colorectal cancer," Clinical Cancer Research, vol. 10, no. 8, pp. 2694-2704, 2004.

[137] M. Ziche, L. Morbidelli, R. Choudhuri et al., "Nitric oxide synthase mediates vascular endothelial growth factor but not basic fibroblast growth factor induced angiogenesis," FASEB Journal, vol. 11, no. 3, p. A196, 1997.

[138] W. Komatsu, K. Ishihara, M. Murata, H. Saito, and K. Shinohara, "Docosahexaenoic acid suppresses nitric oxide production and inducible nitric oxide synthase expression in interferon- $\gamma$ plus lipopolysaccharide-stimulated murine macrophages by inhibiting the oxidative stress," Free Radical Biology and Medicine, vol. 34, no. 8, pp. 1006-1016, 2003.

[139] D. R. Jeyarajah, M. Kielar, J. Penfield, and C. Y. Lu, "Docosahexaenoic acid, a component of fish oil, inhibits nitric oxide production in vitro," Journal of Surgical Research, vol. 83, no. 2, pp. 147-150, 1999.

[140] V. Boutard, B. Fouqueray, C. Philippe, J. Perez, and L. Baud, "Fish oil supplementation and essential fatty acid deficiency reduce nitric oxide synthesis by rat macrophages," Kidney International, vol. 46, no. 5, pp. 1280-1286, 1994.

[141] B. A. Narayanan, N. K. Narayanan, B. Simi, and B. S. Reddy, "Modulation of inducible nitric oxide synthase and related proinflammatory genes by the omega-3 fatty acid docosahexaenoic acid in human colon cancer cells," Cancer Research, vol. 63, no. 5, pp. 972-979, 2003.

[142] B. A. Narayanan, N. K. Narayanan, D. Desai, B. Pittman, and B. S. Reddy, "Effects of a combination of docosahexaenoic acid and 1,4-phenylene bis(methylene) selenocyanate on cyclooxygenase 2 , inducible nitric oxide synthase and $\beta$-catenin pathways in colon cancer cells," Carcinogenesis, vol. 25, no. 12, pp. 24432449, 2004

[143] R. Tevar, D. H. Jho, T. Babcock, W. S. Helton, and N. J. Espat, " $\omega$-3 fatty acid supplementation reduces tumor growth and vascular endothelial growth factor expression in a model of progressive non-metastasizing malignancy," Journal of Parenteral and Enteral Nutrition, vol. 26, no. 5, pp. 285-289, 2002.

[144] D. P. Rose and J. M. Connolly, "Antiangiogenicity of docosahexaenoic acid and its role in the suppression of breast cancer cell growth in nude mice," International Journal of Oncology, vol. 15, no. 5, pp. 1011-1015, 1999.

[145] M. Mukutmoni-Norris, N. E. Hubbard, and K. L. Erickson, "Modulation of murine mammary tumor vasculature by dietary n-3 fatty acids in fish oil," Cancer Letters, vol. 150, no. 1, pp. 101$109,2000$.

[146] A. Bommareddy, B. L. Arasada, D. P. Mathees, and C. Dwivedi, "Chemopreventive effects of dietary flaxseed on colon tumor development," Nutrition and Cancer, vol. 54, no. 2, pp. 216-222, 2006.
[147] M. B. Sporn, “The war on cancer," Lancet, vol. 347, pp. 1377-1381, 1996.

[148] A. E. Aplin, A. Howe, S. K. Alahari, and R. L. Juliano, "Signal transduction and signal modulation by cell adhesion receptors: the role of integrins, cadherins, immunoglobulin-cell adhesion molecules, and selectins," Pharmacological Reviews, vol. 50, no. 2, pp. 197-263, 1998.

[149] G. Christofori and H. Semb, "The role of the cell-adhesion molecule E-cadherin as a tumour-suppressor gene," Trends in Biochemical Sciences, vol. 24, no. 2, pp. 73-76, 1999.

[150] M. B. Schaefer, A. Wenzel, T. Fischer et al., "Fatty acids differentially influence phosphatidylinositol 3-kinase signal transduction in endothelial cells: impact on adhesion and apoptosis," Atherosclerosis, vol. 197, no. 2, pp. 630-637, 2008.

[151] S. Ambs, S. P. Hussain, and C. C. Harris, "Interactive effects of nitric oxide and the p53 tumor suppressor gene in carcinogenesis and tumor progression," FASEB Journal, vol. 11, no. 6, pp. 443-448, 1997.

[152] L. C. Jadeski, C. Chakraborty, and P. K. Lala, "Role of nitric oxide in tumour progression with special reference to a murine breast cancer model," Canadian Journal of Physiology and Pharmacology, vol. 80, no. 2, pp. 125-135, 2002.

[153] J. P. Cooke and D. W. Losordo, "Nitric oxide and angiogenesis," Circulation, vol. 105, no. 18, pp. 2133-2135, 2002.

[154] L. Yi, Q. Y. Zhang, and M. T. Mi, "Role of Rho GTPase in inhibiting metastatic ability of human prostate cancer cell line PC-3 by omega-3 polyunsaturated fatty acid," Chinese Journal of Cancer, vol. 26, no. 12, pp. 1281-1286, 2007.

[155] M. Goua, S. Mulgrew, J. Frank, D. Rees, A. A. Sneddon, and K. W. J. Wahle, "Regulation of adhesion molecule expression in human endothelial and smooth muscle cells by omega-3 fatty acids and conjugated linoleic acids: involvement of the transcription factor NF- $\kappa$ B?" Prostaglandins Leukotrienes and Essential Fatty Acids, vol. 78, no. 1, pp. 33-43, 2008.

[156] R. Ohno, K. Yoshinaga, T. Fujita et al., "Depth of invasion parallels increased cyclooxygenase-2 levels in patients with gastric carcinoma," Cancer, vol. 91, pp. 1876-1881, 2001.

[157] M. Joo, H. K. Lee, and Y. K. Kang, "Expression of E-cadherin, $\beta$-catenin, CD44s and CD44v6 in gastric adenocarcinoma: relationship with lymph node metastasis," Anticancer Research B, vol. 23, no. 2, pp. 1581-1588, 2003.

[158] I. M. Berquin, I. J. Edwards, and Y. Q. Chen, "Multi-targeted therapy of cancer by omega-3 fatty acids," Cancer Letters, vol. 269, no. 2, pp. 363-377, 2008.

[159] S. Iwamoto, H. Senzaki, Y. Kiyozuka et al., "Effects of fatty acids on liver metastasis of ACL-15 rat colon cancer cells," Nutrition and Cancer, vol. 31, no. 2, pp. 143-150, 1998.

[160] M. Kontogiannea, A. Gupta, F. Ntanios, T. Graham, P. Jones, and S. Meterissian, " $\omega-3$ fatty acids decrease endothelial adhesion of human colorectal carcinoma cells," Journal of Surgical Research, vol. 92, no. 2, pp. 201-205, 2000.

[161] D. P. Rose, J. M. Connolly, and M. Coleman, "Effect of omega3 fatty acids on the progression of metastases after the surgical excision of human breast cancer cell solid tumors growing in nude mice," Clinical Cancer Research, vol. 2, no. 10, pp. 17511756, 1996.

[162] M. Lucas, E. Dewailly, G. Muckle et al., "Gestational age and birth weight in relation to n-3 fatty acids among inuit (Canada)," Lipids, vol. 39, no. 7, pp. 617-626, 2004.

[163] A. P. Lanier, P. Holck, G. Ehrsam Day, and C. Key, "Childhood cancer among Alaska Natives," Pediatrics, vol. 112, no. 5, article e396, 2003. 
[164] C. H. MacLean, S. J. Newberry, W. A. Mojica et al., "Effects of omega-3 fatty acids on cancer risk: a systematic review," Journal of the American Medical Association, vol. 295, no. 4, pp. 403-415, 2006.

[165] Y. Q. Chen, I. M. Berquin, L. W. Daniel et al., "Omega-3 fatty acids and cancer risk," Journal of the American Medical Association, vol. 296, no. 3, pp. 278-282, 2006.

[166] D. J. Hunter, E. B. Rimm, F. M. Sacks et al., "Comparison of measures of fatty acid intake by subcutaneous fat aspirate, food frequency questionnaire, and diet records in a free-living population of US men," American Journal of Epidemiology, vol. 135, no. 4, pp. 418-427, 1992.

[167] J. M. Ward and D. E. Devor-Henneman, "Mouse models of human familial cancer syndromes," Toxicologic Pathology, vol. 32, supplement 1, pp. 90-98, 2004.

[168] K. Maddison and A. R. Clarke, "New approaches for modelling cancer mechanisms in the mouse," Journal of Pathology, vol. 205, no. 2, pp. 181-193, 2005.

[169] P. L. Zock and M. B. Katan, "Linoleic acid intake and cancer risk: a review and meta-analysis," American Journal of Clinical Nutrition, vol. 68, no. 1, pp. 142-153, 1998.

[170] C. H. Maclean, S. J. Newberry, W. A. Mojica et al., "Effects of omega-3 fatty acids on cancer," Evidence Report, no. 113, pp. 1-4, 2005.

[171] R. S. Pardini, "Nutritional intervention with omega-3 fatty acids enhances tumor response to anti-neoplastic agents," ChemicoBiological Interactions, vol. 162, no. 2, pp. 89-105, 2006.

[172] W. E. Hardman, C. P. R. Avula, G. Fernandes, and I. L. Cameron, "Three percent dietary fish oil concentrate increased efficacy of doxorubicin against MDA-MB 231 breast cancer xenografts," Clinical Cancer Research, vol. 7, no. 7, pp. 2041-2049, 2001.

[173] Y. Shao, L. Pardini, and R. S. Pardini, "Dietary menhaden oil enhances mitomycin $\mathrm{C}$ antitumor activity toward human mammary carcinoma MX-1," Lipids, vol. 30, no. 11, pp. 10351045, 1995.

[174] J. Chen, E. Hui, T. Ip, and L. U. Thompson, "Dietary flaxseed enhances the inhibitory effect of tamoxifen on the growth of estrogen-dependent human breast cancer (MCF-7) in nude mice," Clinical Cancer Research, vol. 10, no. 22, pp. 7703-7711, 2004.

[175] P. Bougnoux, N. Hajjaji, M. N. Ferrasson, B. Giraudeau, C. Couet, and O. Le Floch, "Improving outcome of chemotherapy of metastatic breast cancer by docosahexaenoic acid: a phase II trial," British Journal of Cancer, vol. 101, no. 12, pp. 1978-1985, 2009.

[176] A. Rusca, A. F. D. Di Stefano, M. V. Doig, C. Scarsi, and E. Perucca, "Relative bioavailability and pharmacokinetics of two oral formulations of docosahexaenoic acid/eicosapentaenoic acid after multiple-dose administration in healthy volunteers," European Journal of Clinical Pharmacology, vol. 65, no. 5, pp. 503-510, 2009.

[177] C. E. Childs, M. Romeu-Nadal, G. C. Burdge, and P. C. Calder, "Gender differences in the n-3 fatty acid content of tissues," Proceedings of the Nutrition Society, vol. 67, no. 1, pp. 19-27, 2008.

[178] L. M. Arterburn, E. B. Hall, and H. Oken, "Distribution, interconversion, and dose response of n-3 fatty acids in humans," American Journal of Clinical Nutrition, vol. 83, supplement 6, pp. 1467S-1476S, 2006.

[179] R. A. Murphy, M. Mourtzakis, and V. C. Mazurak, "n-3 polyunsaturated fatty acids: the potential role for supplementation in cancer," Current Opinion in Clinical Nutrition \& Metabolic Care, vol. 15, no. 3, pp. 246-251, 2012. 

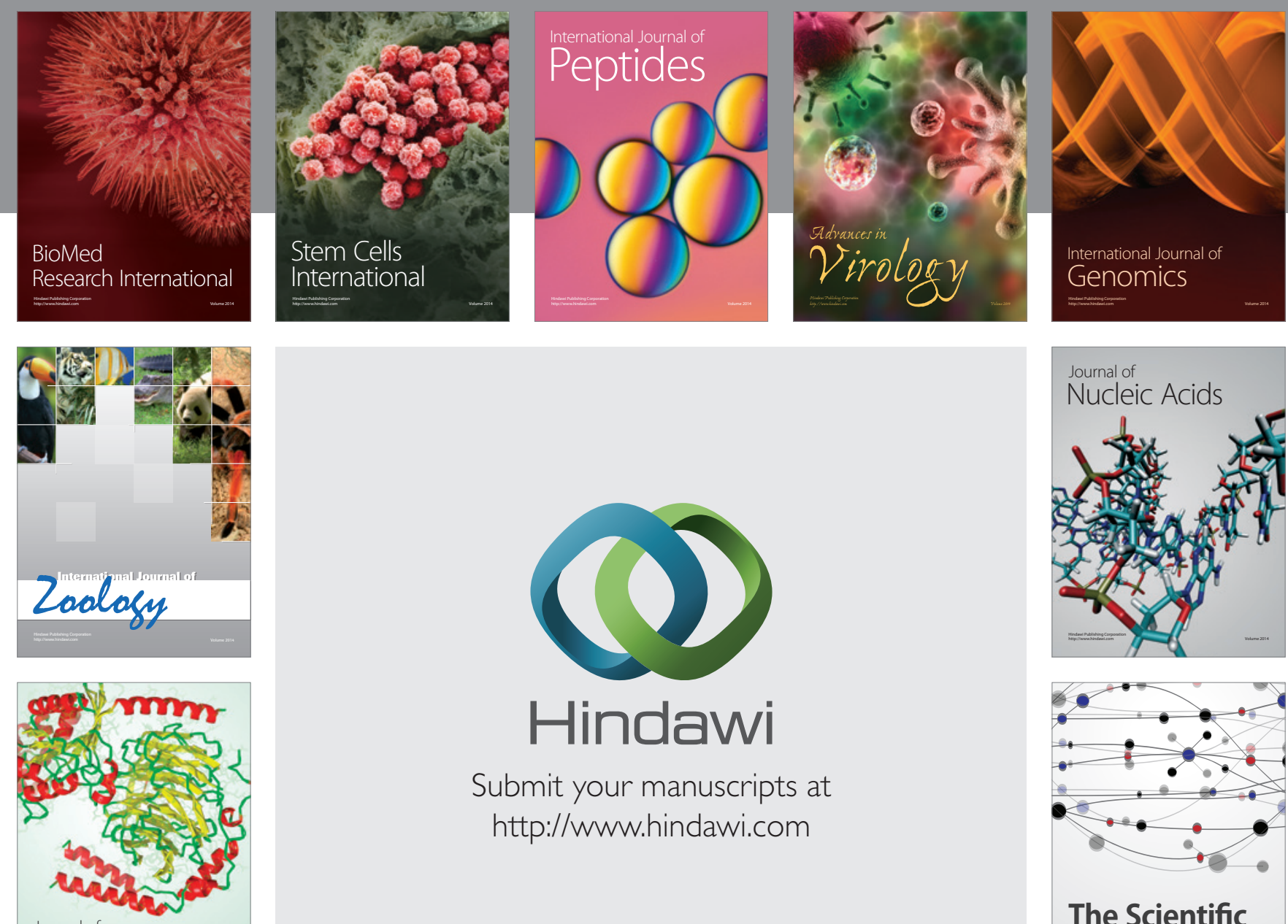

Submit your manuscripts at

http://www.hindawi.com

Journal of
Signal Transduction
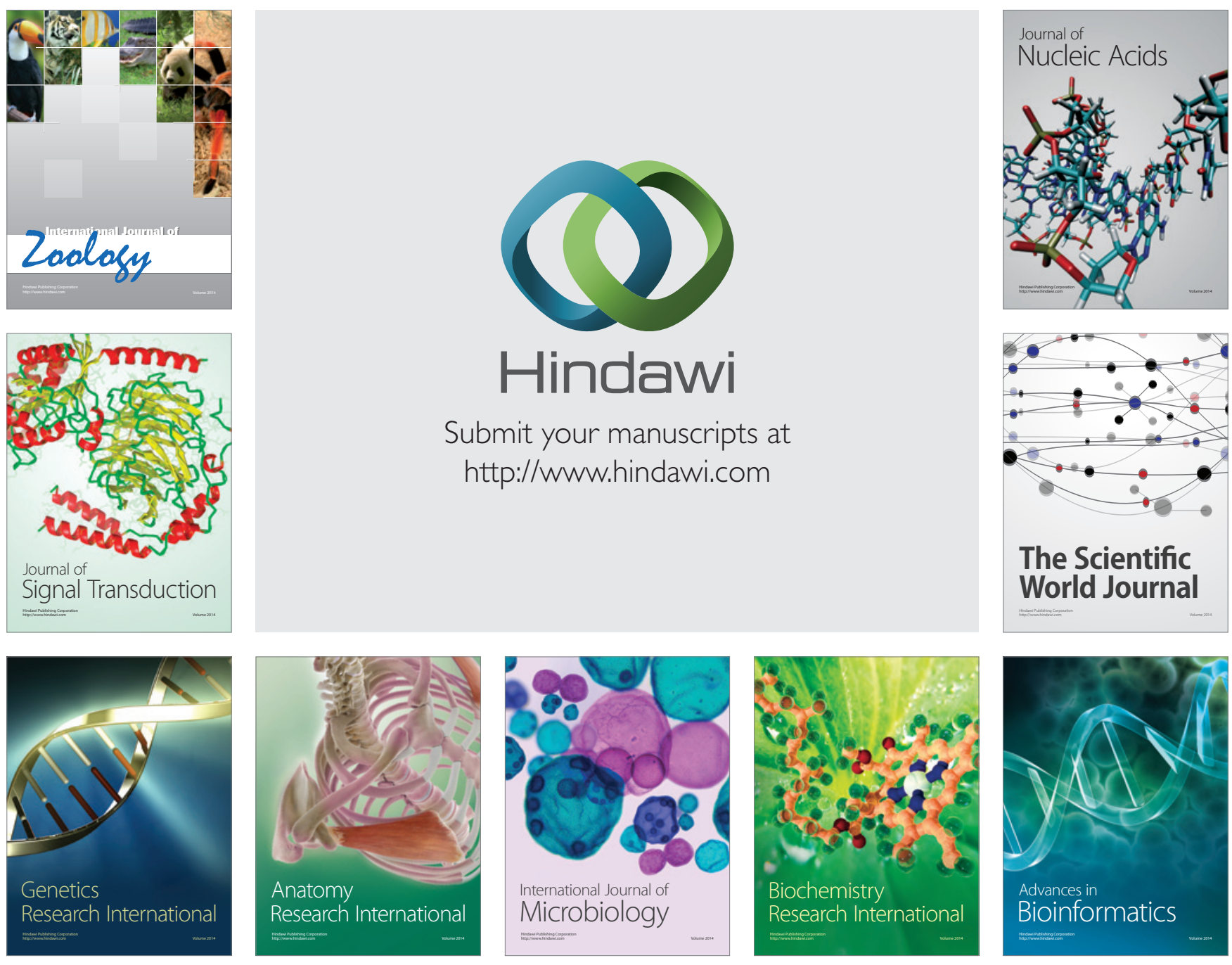

The Scientific World Journal
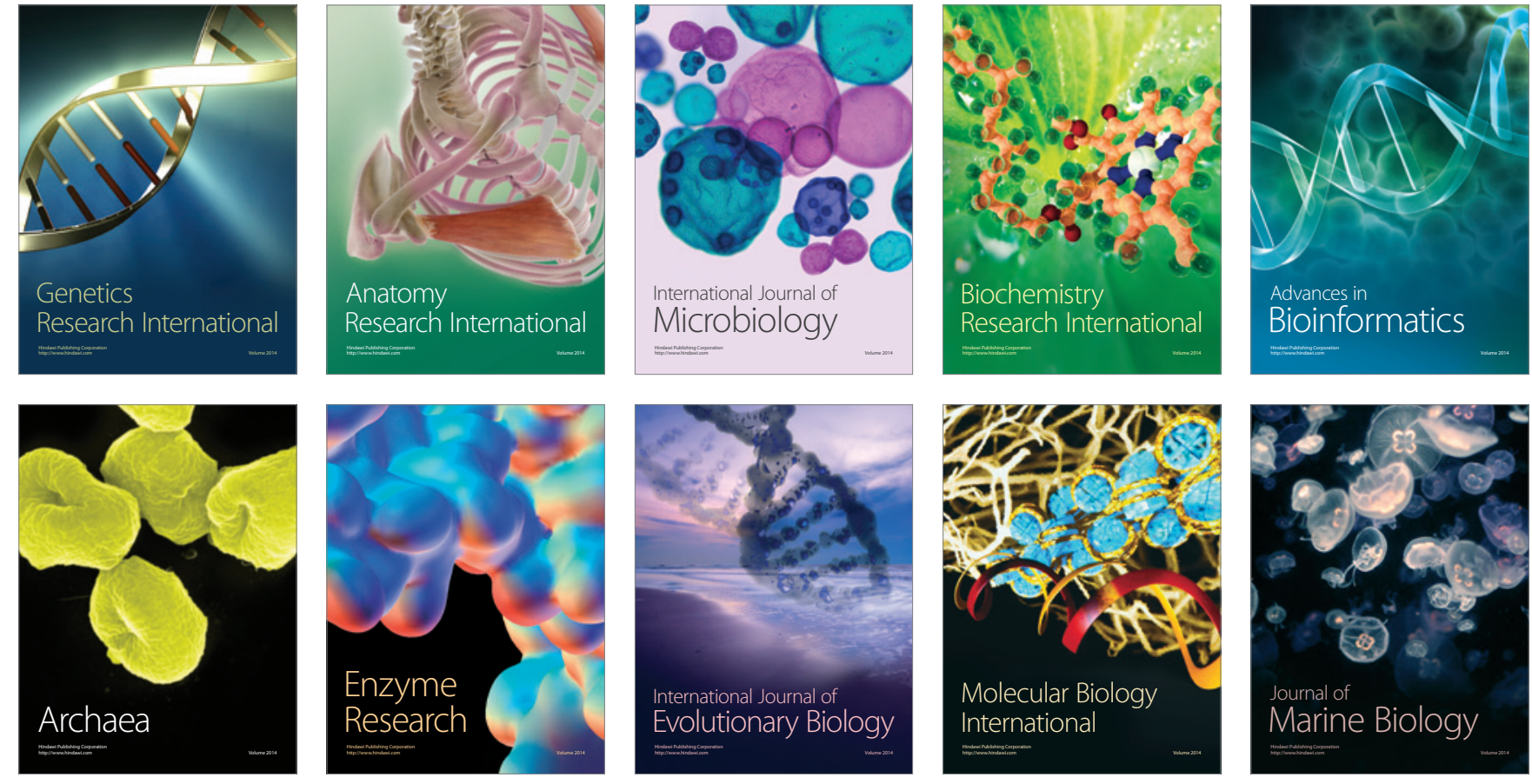